\title{
Pemanfaatan Digital Marketing dalam Promosi Pariwisata pada Era Industri 4.0
}

\author{
I Gede Agus Krisna Warmayana \\ aguskrisna@ihdn.ac.id \\ Institut Hindu Dharma Negeri Denpasar
}

\begin{abstract}
Digital marketing is promoting online can use website and mobile media. In industry 4.0 is an automatic trend to carry out activities in the business field. The use of digital marketing in the industrial era 4.0 in the world of tourism is very influential supported by 5 digital marketing applications, namely websites, online advertising, social media, web forums and mobile applications. By applying digital marketing tourism will grow professionally and globally.
\end{abstract}

Keywords: Digital Maerketing, Industry 4.0, tourism

\section{Pendahuluan}

Pada era industri 4.0 Teknologi informasi dan komunikasi (TIK) merupakan sarana yang membantu dalam kehidupan dalam berbagai bidang termasuk dalam dunia pariwisata. Di zaman sekarang menjadi suatu kebutuhan mendasar dalam sebuah orginasasi, perusahaan, instansi pemerintah dan instansi pendidikan. Peranan TIK dalam dunia pariwisata sebagai sarana dan prasarana dalam mempromosikan pariwisata yang sering kita dengar secara elektronik dengan nama digital marketing.

Hubungan era industry 4.0 dengan digital marketing sangat berhubungan dengan prinsip yang terintegrasi satu sama lain. Revolusi industry 4.0 diantaranya (Hasmaidi.com, 2018) :

1. Revolusi Industri 1, pertama kali terjadi pasca ditemukan mesin uap, sehingga terjadinya perkembangan dan pertumbuhan yang besar dalam mesin-mesin industri di Inggris pada Tahun 1764. revolusi ini berdampak pada sector pertanian dan manufactur / industri terutama industri tekstil dan turunya

2. Revolusi Industri ke 2 adalah diawal abad ke 19, dimana terjadinya perbaikan pada sisi proses, dimana proses dalam skala besar (mass production) dikenal juga berkat inovasi dari ford. penemuan pada masa ini lebih kearah listrik dan transportasi, kombinasi cara produksi dan perkembangannya ini berpengaruh pada teknologi terutama untuk industri besi, mesin-mesin, minyak, kimia, kendaraan dan lain-lain

3. Revolusi Industri Ke 3, dikenal masa otomasi, pasca perang dunia, ditandai dengan penggunaan teknologi tinggi otomatis, menggunakan elektronik dan teknologi informasi. inilah yang berlangsung sampai hari ini. dimana mesin dan peningkatan kapasitas produksi dan software menjadi pendukung utama pada proses manufactur.

4. Revolusi Industri ke 4 yang saat ini dihadapai menjelaskan bahwa mesin dan kapasitas produksi saja, tidak cukup membuat pertumbuhan bagi suatu negara.Seiring dengan hal itu perkembangan teknologi informasi saat ini, software dan hardware serta pesatnya perkembangan penggunaan internet, maka oleh forum ekonomi dunia 
(World Economic Forum) menamakan gelombang perubahan saat ini, dengan gelombang perubahan yang melibatkan sejumlah gabungan teknologi perangkat dan software yang menyatukan hal fisik dan digital, yang memiliki dampak luas, jauh lebih besar dibadingkan revolusi industri sebelumnya, industri, teknologi ini diyakini akan mampu meningkatkan produktivitas hingga 30\%. Revolusi industri 4.0 ini tidak hanya merupakan pengembangan dari teknologi sebelumnya, namun bakal mampu mematikan bisnis konvesional, akibat dunia sudah tersambung dengan dunia internet dan teknologi informasi seperti transportasi online mampu mematikan industri salah satunya jasa transportasi yang ada saat ini. Revolusi industri 4.0 ini akan memberikan efek meperdekat jarak antara produsen dan taget marketnya. yang menjadi penggerak terbesar dari transformasi digital adalah teknologi informasi. TIK yang sudah dimanfaatkan dalam semua bidang. tik mampu mengantarkan produsen dengan cepat kepada target market, dan memudahkannya untuk mendapatkan pebiayaan, dan dapat bertumbuh dengan cepat dengan pengembangkan jangkauan produk tanpa batas dengan dukungan kecepatan teknologi yang diakses. Namun bagaimanapun manusia adalah komponen terpenting "Man Behind The Gun" jadi pengembangan sumber daya manusia sangat penting. pada zamannya saat ini , sumber daya manusia yang terlibat langsung saat ini adalah generasi X yang lahir Tahun 1965-1980, Gen Y (Generasi Millenial) yang lahir antara 1981-1994 dan generasi $Z$ lahir 1995-2010 yang memang merupakan pelopor revolusi industri 4.0. Industri 4.0 adalah nama tren otomatis dan pertukaran data terkini dalam teknologi seperti gambar 2

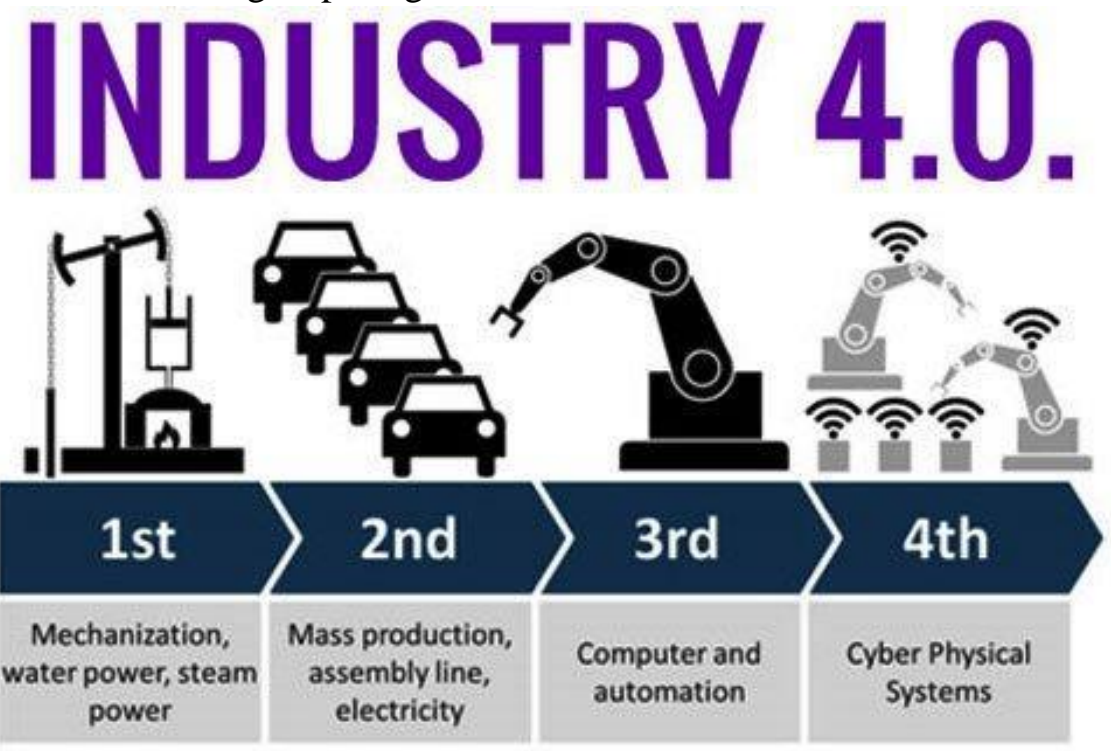

Gambar 1. Revolusi Industri 4.0

( hasmaidi.com)

Industri 4.0 di bidang pariwisata menekankan pada Tourism and The Digital Transformation atau Pariwisata dan Transformasi Digital. Pada jurnal ini akan membahas mengenai pemanfaatkan digital marketing bidang pariwisata di Bali yang dilatar belakangi oleh industri 4.0 dan perilaku generasi Y dan Z. 


\section{INDUSTRY 4.0}

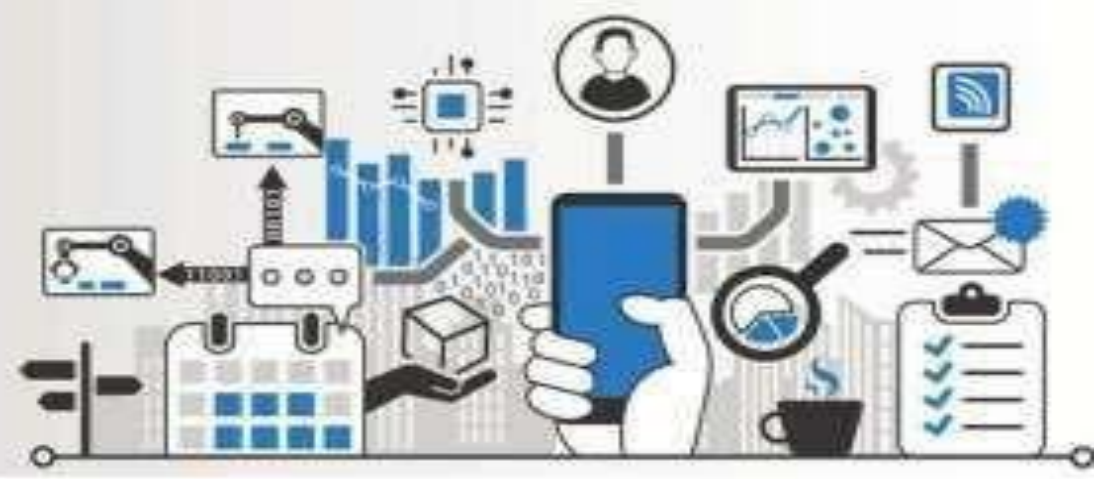

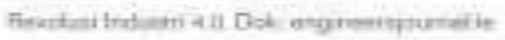

Gambar 2. Industri 4.0

Pengertian digital marketing menurut sumber (redtreeasia.com, 2018) adalah suatu usaha untuk melakukan pemasaran sebuah brand atau produk melalui dunia digital atau internet. Tujuannya ialah untuk menjangkau konsumen maupun calon konsumen secara cepat dan tepat waktu.

Digital marketing ialah suatu cara untuk mempromosikan produk / brand tertentu melalui media internet. Bisa melalui iklan di internet, facebook, youtube, ataupun media sosial lainnya.

Berdasarkan informasi pengguna internet di Indonesia masuk peringkat 6 besar dunia sampai tahun 2018 sepeti gambar 3.1 (Kominfo.go.id, 2018).

\begin{tabular}{|c|c|c|c|c|c|c|}
\hline & 2013 & 2014 & 2015 & 2016 & 2017 & 2018 \\
\hline 1. Chima- & 620.7 & 6.436 & 669.8 & 700,7 & 7362 & 777.0 \\
\hline 2 us- - & 245.0 & 2529 & 259.3 & 264.9 & 269.7 & 274.1 \\
\hline I. enctia & 1672 & 2156 & 2523 & 283.8 & 3138 & 34.6 .3 \\
\hline 4 Erazill & 902 & $107>$ & 7337 & 1798 & $123: 3$ & 125.9 \\
\hline 5 saparn & 1000 & 1027 & 7036 & 1045 & 105.0 & $705: 4$ \\
\hline 6 Inctonesta & 728 & 83.7 & $93: 4$ & 102.8 & 1126 & 123.0 \\
\hline 7 . Russia & 77.5 & 829 & 873 & 91.4 & 94.3 & $96: 0$ \\
\hline 8. Germany & 59.5 & 67.6 & 622 & 62.5 & $62: 7$ & 62.7 \\
\hline 9. Mexico & 53.7 & 594 & 65,1 & 70.7 & 75.7 & 80.4 \\
\hline 10. Nigeria & 51.8 & 577 & 632 & 69.7 & 76.2 & 8. 3 \\
\hline 17 UKC- & 488 & 50.7 & 573 & 52.4 & 53,4 & 54.3 \\
\hline 12 framce & $48 \mathrm{~B}$ & 497 & 50.5 & 51.2 & 51.9 & 525 \\
\hline 13 Philipoines & 423 & 48.0 & 53.7 & 59.7 & 64.5 & 69.3 \\
\hline
\end{tabular}

Gambar 3.1 Pengguna Internet 


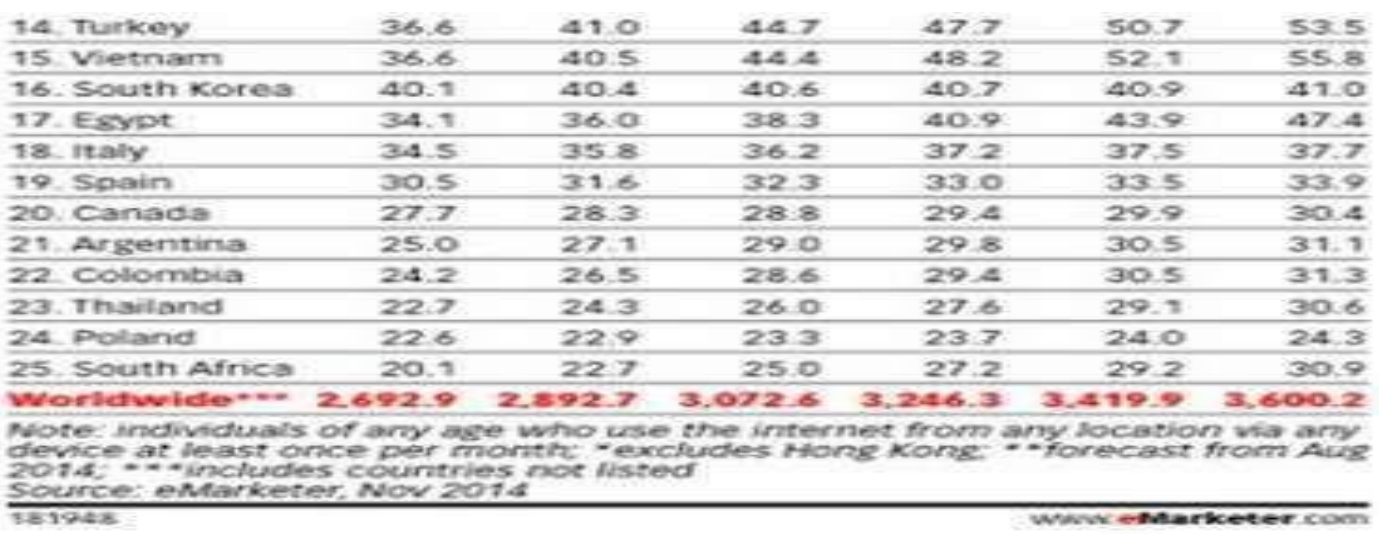

Gambar 3.2 Pengguna Internet

Berdasarkan data dari Kementerian Pariwisata bahwa 63\% dari keseluruhan kegiatan travelling saat ini dicari, dipesan dan dijual secara online dan $50 \%$ dari penjualan online travel menggunakan lebih dari satu gadget, bahkan sekitar 200 lebih ulusan mengenai travelling permenitnya telah diposting di TripAvisor.

\section{Pembahasan}

Pariwisata merupakan salah satu sektor pembangunan yang saat ini sedang digalakkan oleh pemerintah. Tujuan pengembangan pariwisata di Indonesia terlihat dengan jelas dalam Instruksi PresidenRepublik Indonesia Nomor 9 Tahun 1969, khususnya Bab II Pasal 3, yang menyebutkan "Usaha pengembangan pariwisata di Indonesia bersifat suatu pengembangan "industri pariwisata" dan merupakan bagian dari usaha pengembangan dan pembangunan serta kesejahtraan masyarakat dan Negara (Yoeti, 1996). Beberapa jenis objek wisata yang ada di Indonesia, antara lain:

1. Wisata Alam.

Indonesia memiliki kawasan terumbu karang terkaya di Dunia dengan lebih dari 18\% terumbu karang di dunia. Serta lebih dari 3000 species ikan, 590 jenis karang batu dan banyak lagi objek wisata yang sangat menarik. Seperti Raja Ampat di Papua Barat, Teluk Kiluan di Lampung dan Pulau Derawan

2. Wisata Belanja.

Wisata di Indonesia terbagi dengan pusat belanja modern dan tradisional. Contohnya pusat belanja modern seperti mall dan setiap tahun selalu ada Jakarta Great Sale yang memberikan diskon secara besar-besaran. Sedangkan pasar tradisional seperti Pasar Beringharjo di Jogjakarta, Pasar Klewer di Solo atau Pasar Terapung di Sungai Barito Banjarmasin.

3. Wisata Budaya.

Berdasarkan data sensus 2010, Indonesia terdiri dari 1.128 suku bangsa. Sehingga Indonesia terkenal dengan kayanya budaya tradisional, misalnya sendratari Ramayana yang sering di pentaskan di Candi Prambanan. Tari Kecak, Tari Legong di Bali. Serta tari Piring dari Padang.

4. Wisata Religi.

Wisata Religi di Indonesia cukup banyak, misalnya Wisata Religi ke makam

Walisongo, atau kebeberapa peninggalan sejarah yang menggambarkan agama Budha di Candi Borobudur.

Digital Marketing Pariwisata adalah usaha mempromosikan dan memasarkan sebuah daerah/daya tarik wisata dengan menggunakan media digital. Adapun aktivitas digital marketing meliputi : website, social media, online advertising,

email direct marketing, forum discussion, mobile applications. (digitalmarketingpariwisata.com, 2018). 
Perlikau genarasi $\mathrm{Y}$ dan $\mathrm{Z}$ yang semakin digital dalam kehidupan sehari-harinya yang dikenal dengan always connected travelers yang artinya dimanapun berada dan kapanpun bisa saling terkoneksi menggunakan device maupun mobile. Serperti Gambar 4.

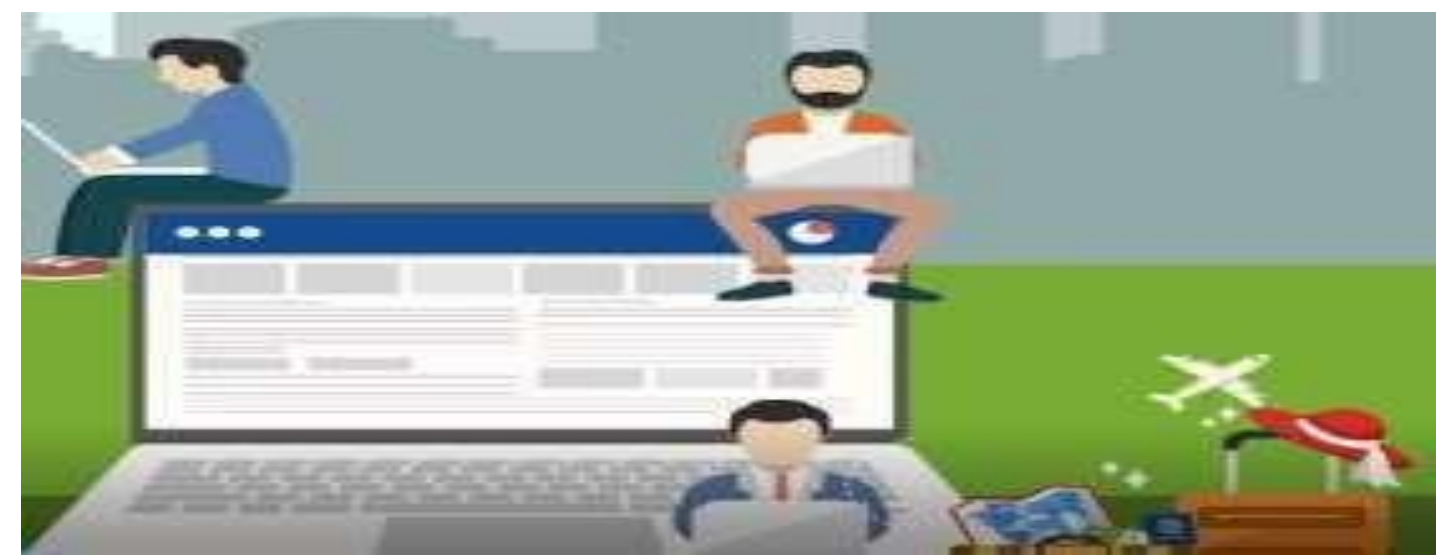

Gambar 3. always connected travelers

3 jargon penting upaya Go Digital oleh Kementerian Pariwisata Indonesia (Pariwisata, 2018) yaitu:

1. The More digital, the more personal adalah semangkin digital kita mempromosikan pariwisata secara personal kita dapat mengetahui demografi, psikogafi dan perilaku konsumen secara efektif dan terukur seperti Gambar 4

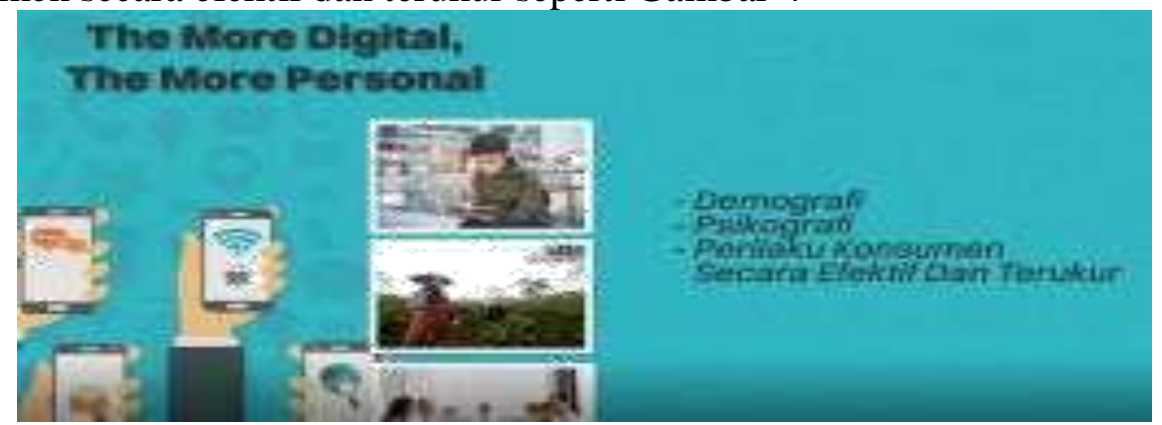

Gambar 4. The More Digital, The More Pesonal

2. The More digital, the more professional adalah semakin digital kita semakin professional mempromosikan pariwista seperti Gambar 5 mengintegrasikan paid, owned dan social media menggunakan bigdata.

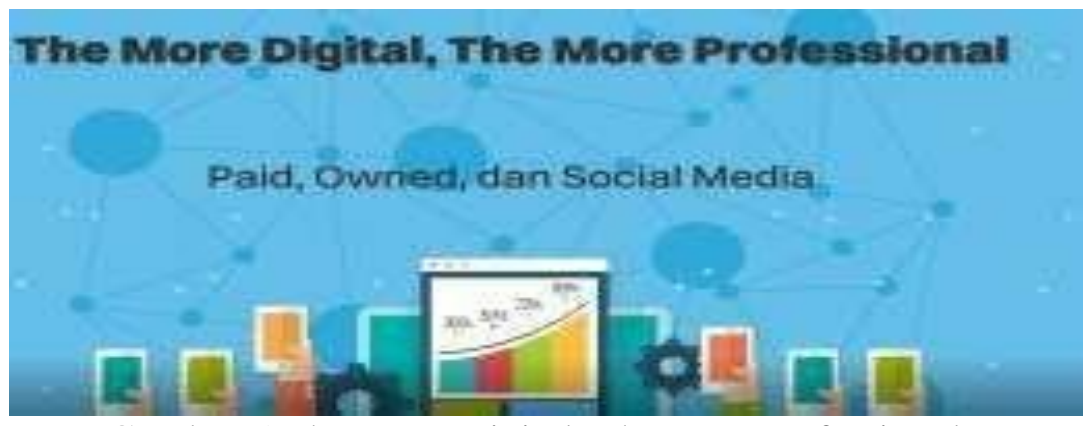

Gambar 5 The More Digital, The More Pofessional 
3. The More digital, the more global adalah semakin digital kita maka kita mengjakau konsumen berbagai negara seperti pada Gambar 6.

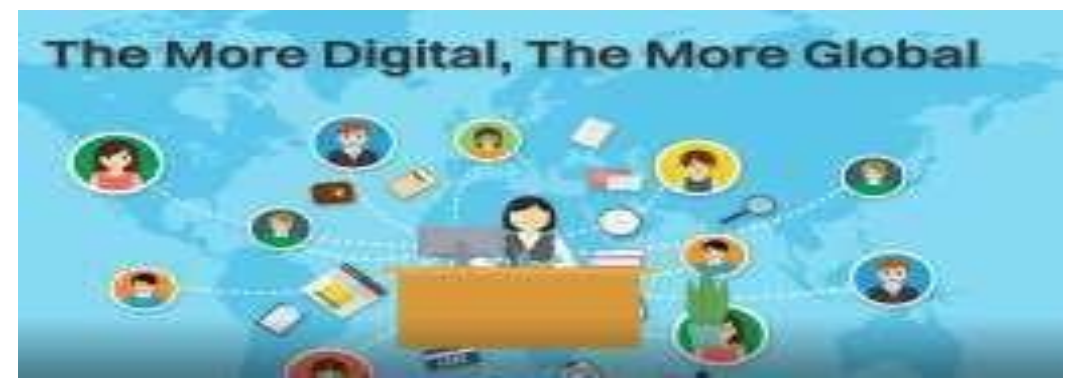

Gambar 6 The More Digital, The More Global

Ada beberapa penelitian untuk mempromosikan pariwisata diantaranya:

1. Strategi Pengembangan Bisnis Pada Bisnis Pariwisata bahwa strategi bisnis terbaik adalah dengan melakukan Diversifikasi Produk, yaitu perubahan pangsa pasar dengan melakukan kombinasi dengan perubahan produk. Alternatif lain adalah dengan Penetrasi Pasar, Pengembangan Produk atau Pengembangan Pasar (Umar, Sasongko, Aguzman, \& Nusantara, 2014)

2. Peran Digital Marketing Terhadap Brand Equity Produk Pariwisata bahwa kemajuan teknologi, perubahan perilaku konsumen, dan inovasi perusahaan sangat mempengaruhi brand equity suatu produk khususnya di bidang pariwisata ( $\mathrm{P}$, Fauziyyah, Jember, Jember, \& Jember, 2017).

3. Analisa Strategi Pengembangan E-Tourism Sebagai Promosi Pariwisata Di Pulau Lombok bahwa dari analisis SWOT terkait dengan evaluasi pengembangan $e$ tourism di Pulau Lombok diketahui bahwa strategi yang harus digunakan pemerintah adalah strategi $W O$ yaitu berfokus untuk melakukan koordinasi secara internal, melakukan evaluasi diri terhadap penerapan e-tourism serta evaluasi yang sistematis terhadap penerapan promosi melalui internet dan meningkatkan strategi promosi pariwisata melalui internet (Irfan \& Apriani, 2017)

4. Perancangan Sistem Informasi Wisata Religi Berbasis Website di Bali jurnal ini membahas rancang bangun membuat system informasi pariwisata religi yang berbasis website (Agus \& Warmayana, 2018).

Dari beberapa penelitian diatas bahwa peranan digital marketing sangat berpangaruh untuk mendatangkan pariwisata adapun digital marketing di era industry 4.0 yang bisa di terapakan adalah menerapakan E-tourism (IT enabled tourism / electronic tourism) adalah memanfaatkan kecanggihan teknologi informasi dan komunikasi untuk meningkatkan daya guna dalam bidang pariwisata, memberikan berbagai jasa layanan pariwisata kepada customers dalam bentuk telematika dan menjadikan penyelenggaraan pemasaran pariwisata lebih mudah diakses. E-tourism adalah sebuah cara promosi yang modern dan informasi terkini mengenai pariwisata yang dicari oleh wisatawan, seperti obyek wisata, hotel, agen perjalanan, dan event-event yang dapat diakses 24 jam kapanpun, dimanapun dan siapapun. E-tourism adalah sebuah sistem interaktif online yang mempermudah wisatawan untuk mendapatkan informasi dan melakukan pemesanan beberapa dari elemen pariwisata yang tersedi seperti hotel dan agen perjalanan. E-tourism memiliki prinsip yang diselaraskan dengan pemanfaatannya yaitu dalam peningkatan pembangunan pariwisata. Ada tiga unsur yang menjadi prasyarat dari e-tourism yaitu ICT (Information and Communication Technologies), Tourism dan Business, serta dukungan dari pemerintah. (Novianti, 2018) 
e-tourism yang dapt dikembangkan seperti Gambar 7

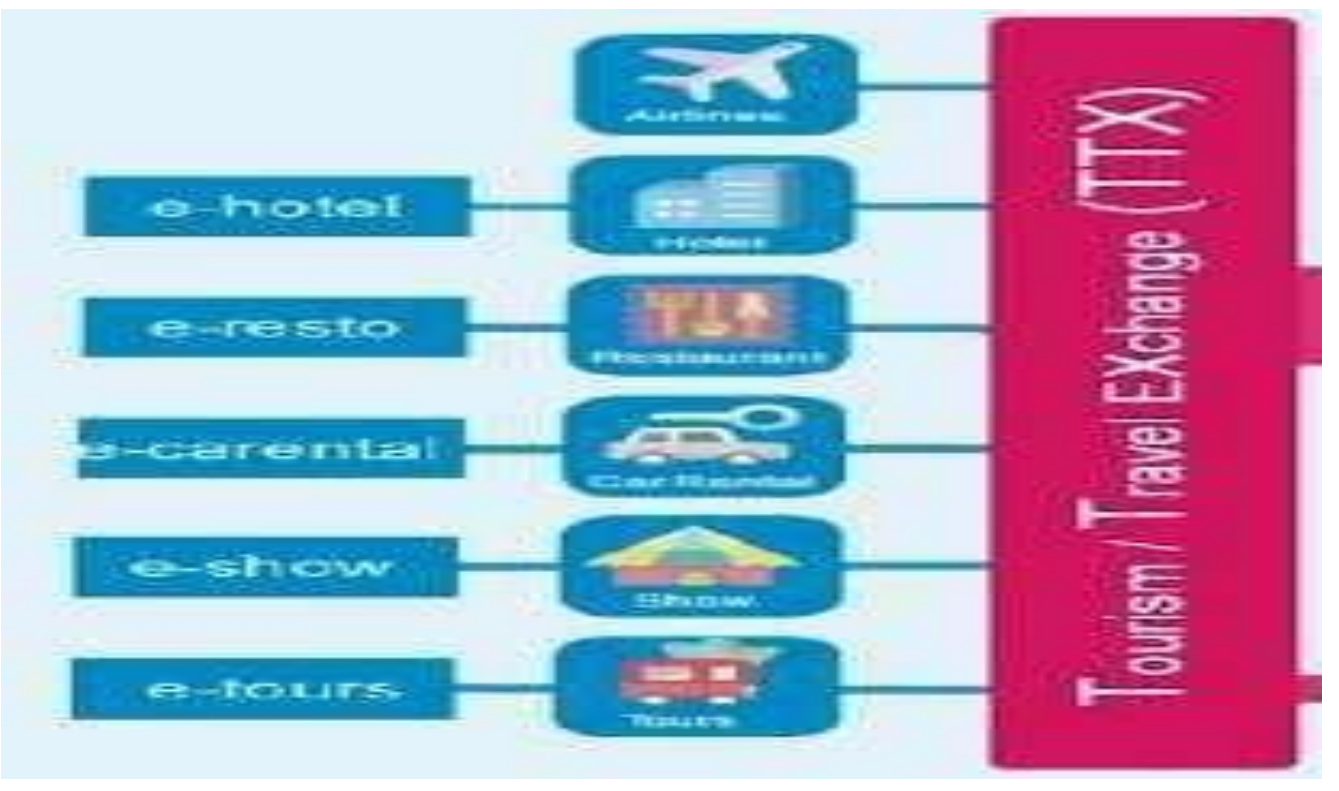

Gambar 7. E- tourism

e-tourism yang bisa di aplikasikan di digital marketing ada 5 (enam)

1. Website

Website atau web adalah halaman informasi yang disediakan melalui internet sehingga bisa diakses diseluruh dunia selama terkoneksi internet, website ada yang dinamis statis. Website yang dinamis adalah web yang bisa di input,update, dan delete kontennya oleh admin web setiap saat sedangkan websiste statis yang tidak bisa langsung di input, update dan delete oleh admin web harus pembuat websitenya atau yang ngerti webnya. Website dibuat dengan CMS (content management system) atau framework atau pemrograman sendiri baik secara professional. Website yang sudah dibuat nanti di SEO (search engine optimization) untuk meningkatkan rangking websitenya dan mudah

ditemukan di search engine seperti di google, yahoo, bing atau yang search engine yang lainnya. Seperti pencarian hotel yang ada di Bali Gambar 8.

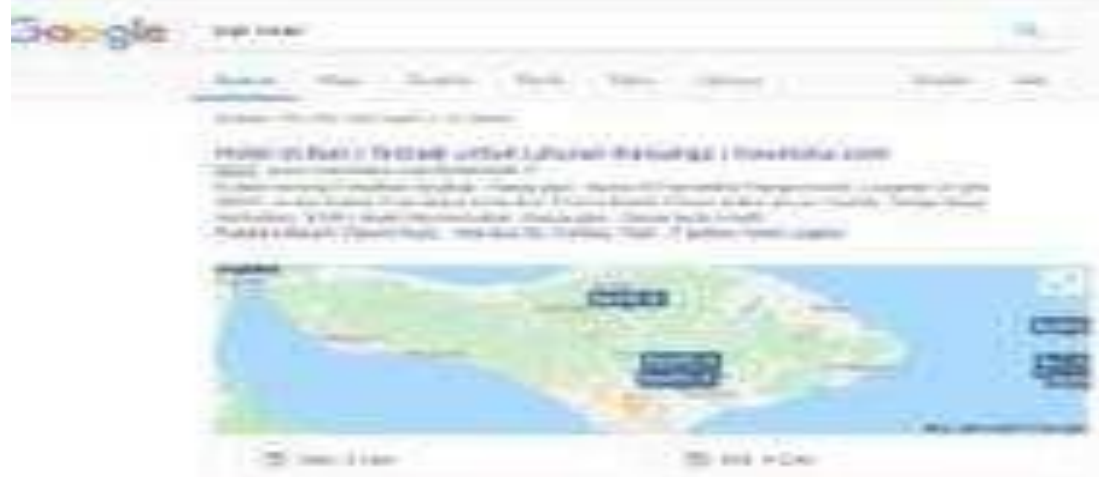

Gambar 8. Pencarian di Search engine 
Website e-tourism adalah website seperti yang berisi informasi konten, gambar atau video seperti tempat wisata, hotel, tours dan lain-lain seperti pada Gambar 8. Ataupun ada website focus pada salah satu bidang usaha seperti hotel, travel, rencart atau yang lainnya. Salah satu contoh website hotel seperti gambar 10.

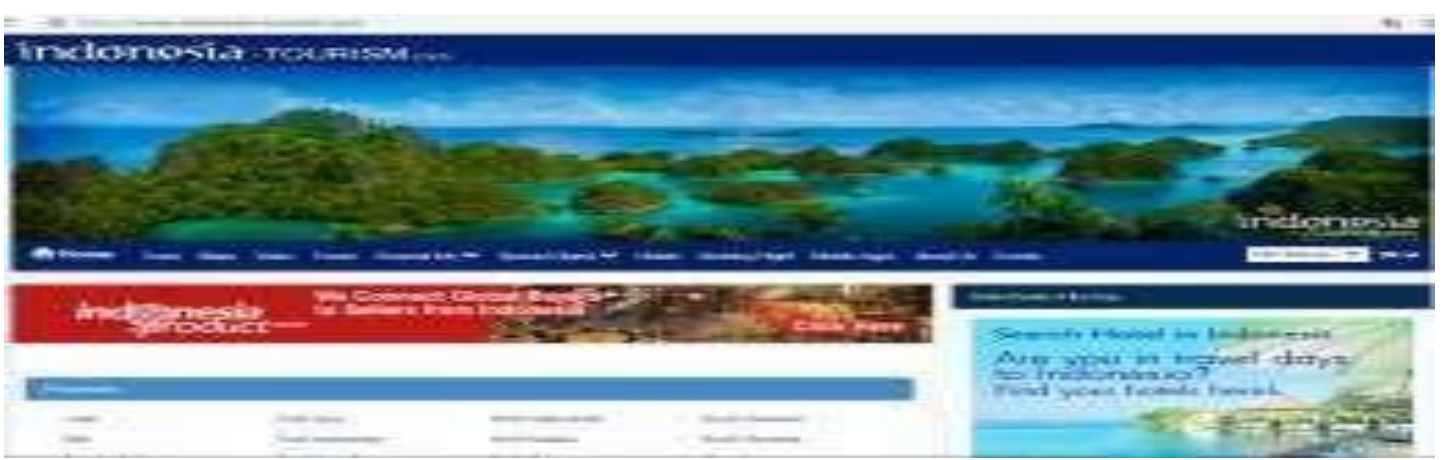

Gambar 9 webiste e-tourism

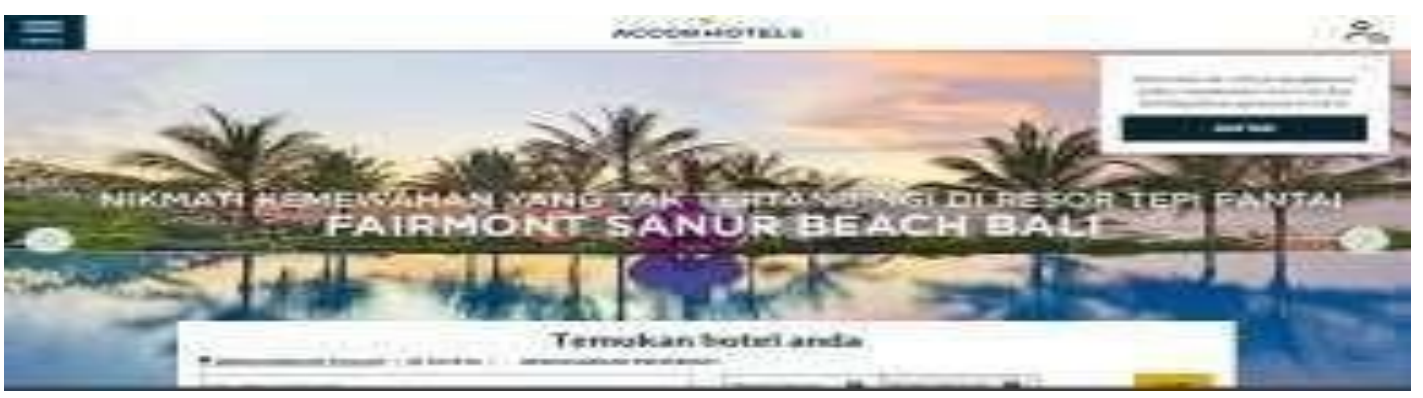

Gambar 10. Website hotel

2. Social Media

Social media adalah media online yang para penggunanya bisa berbagi, berpartisipasi dan menciptakan isi konten text, gambar, vidoe maupun buat streaming online. Media sosial seperti gambar 11 .

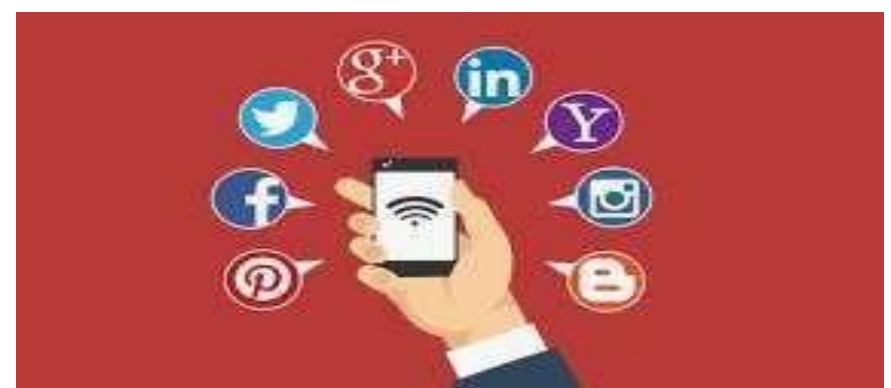

Gambar 11 Media Sosial 
Tiga Media sosial yang populer yang digunakan pada industry 4.0
a. Facebook
b. Instagram
c. Twitter
d. Youtube

Media sosial ini sebelum sebagai ajang mencari pertemanan, chating, sharing video. Perkembang sosial media sebagai media digital di dunia bisnis sebagai media promosi, follower dengan meng upload gambar-gambar atau konten yang akan di promosikan secara webbase maupun mobile. Dengan adanya media sosial untuk mempromosikan pariwisata lebih cepat dan realtime dan bisa di lihat oleh pengguna sosial media.

\section{Online Advertising}

Online advertising adalah iklan yang dibuat secara online atau website untuk menarik pelanggan . contoh penerapan online advertising adalah Gambar 12.

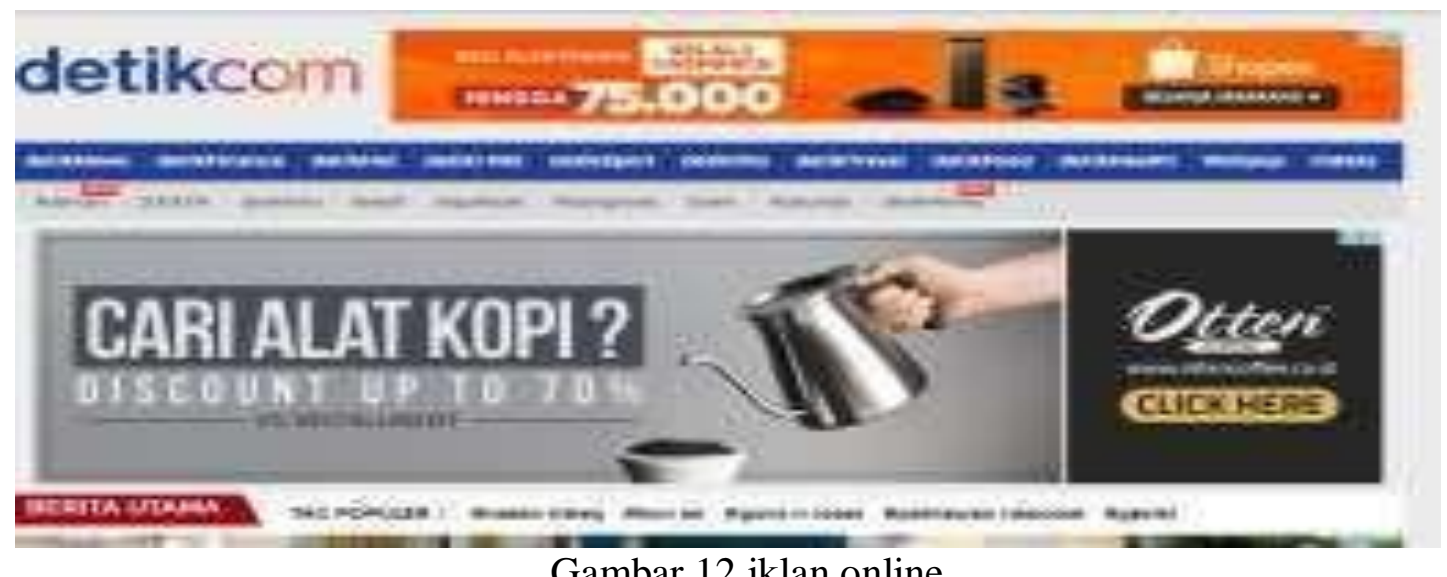

Gambar 12 iklan online

Dengan adanya media iklan online jadi kita lebih cepat memasarkan pariwisata dengan menaruh iklan di website-webiste yang menyediakan tempat pasang iklan online.

\section{Forum discussion.}

Forum discussion adalah kumpulan forum secara online yang memuat data, gambar, animasi, suara, video atau gambungan dari semuanya yang terhubung dalam sebuah jaringan. Hyperlink dimuat bersifat searah. Web forum memiliki topik atau trade untuk dibahas yang dibuat dengan langkah update info dalam web tersebut oleh pembuat web forum tersebut. Topik tersebut ditanggapi atau direspon oleh anggota forum yang ada diwebsite seperti Gambar 13.

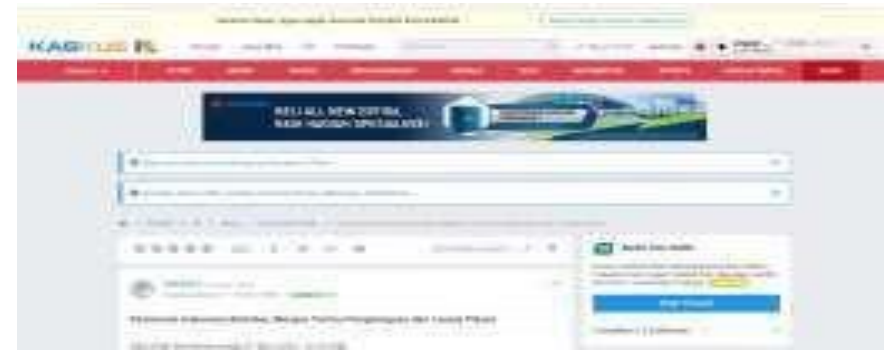

Gambar 13 web forum 


\section{Mobile Applications}

Mobile applications adalah aplikasi mobile yang didesain khusus untuk perangkat smartphone dan tablet. Platform aplikasi mobile ada 4 yaitu android, ios, windows 8 dan windows phone. Aplikasi yang dikembangkan yang berbasis mobile adalah seperti pemesan tiket pesawat atau hotel yang mana bisa dilakukan lewat telepon pintar seprti gambar 14.

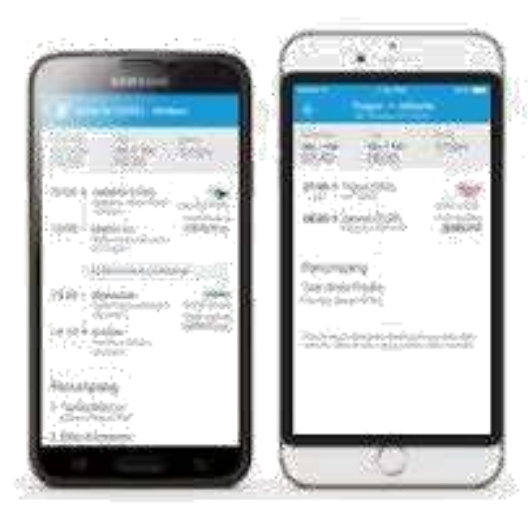

Gambar 14. Aplikasi mobile

Dengan perkembangan mobile yang sekarang semua informasi kita dapatkan dari mobile dan transaksi bisa dilakukan secara mobile.

Aplikasi mobile mendukung Industri 4.0 yang mana sudah terintergrasi satu sama lainnya sepeti pemesan hotel bisa dilakukan secara mobile tanpa perantara staf hotel dari proses cekin sampai proses cek out.

Dengan adanya system yang terintegrasi dan terupdate secara real time baik itu berupa content, gambar, animasi maupun video atau suara akan mempermudah untuk mempromosikan pariwisata secara digital. Satu sisi akan memanjakan pelanggan atau wisatawan untuk mencari tempat-tempat yang diinginkan tanpa perlu lagi ke travel agent. Dan sisi bisnis akan mengurangi biaya operasional, lebih cepat dan lebih professional serta informasi yang disampai bisa langsung seluruh dunia mengetahuinya.

\section{Simpulan}

Pemanfaatan digital marketing di industry 4.0 sangat berperan dalam meningkatkan promosi pariwisata pada generasi $\mathrm{Y}$ dan Z. Digital marketing merupakan suatu keharusan karena generasi ini yang sering digunakan baik disadari maupun tidak. Aplikasi Digital marketing yang akan digunakan diantaranya website, media sosial, online advertising, web forum, mobile aplikasi. Digital marketing kedepannya adanya aplikasi yang memudahkan wisatan untuk melakukan travel dengan system yang otomatis dan adanya multi bahasa. Pemanfaatan digital marketing di era Revolusi industri 4.0 pada dunia pariwisata akan mengubah paradigma industri, namun juga pekerjaan, cara berkomunikasi, berbelanja, bertransaksi, hingga gaya hidup. 


\section{Daftar Pustaka}

Agus, I. G., \& Warmayana, K. (2018). Perancangan Sistem Informasi Wisata Religi Berbasis Website di Bali, 3, 37-58.

$\begin{array}{lllll}\text { Digitalmarketingpariwisata.com. (2018). No Title. Retrieved from } & \text { No }\end{array}$ digitalmarketingpariwisata.com

Hasmaidi.com. (2018). No Title. Retrieved September 10, 2018, from https://hasmaidi.com/pemahaman-revolusi-industri-4

Irfan, P., \& Apriani, D. (2017). ANALISA STRATEGI PENGEMBANGAN ETOURISM SEBAGAI PROMOSI PARIWISATA DI PULAU LOMBOK. ILKOM Jurnal Ilmiah, 9(22), 325-330.

Kominfo.go.id. (2018). No Title. Retrieved September 1, 2018, from https://kominfo.go.id/index.php/content/detail/4286/Pengguna+Internet+Indonesia +Nomor+Enam+Dunia/0/sorotan_media

Novianti, D. T. (2018). No Title. Retrieved September 1, 2018, from http://repository.library.uksw.edu/handle/123456789/2435

P, N. L. I., Fauziyyah, S., Jember, U., Jember, U., \& Jember, U. (2017). PERAN DIGITAL MARKETING TERHADAP BRAND EQUITY PRODUK PARIWISATA, 2017, 27-28.

Pariwisata, Kementerian . (2018). No Title, 1.

Redtreeasia.com. (2018). No Title. Retrieved September 29, 2018, from http://redtreeasia.com/info/apa-itu-digital-marketing-pengertian-dan-konsepdasarnya/

Umar, A., Sasongko, A. H., Aguzman, G., \& Nusantara, U. B. (2014). STRATEGI PENGEMBANGAN BISNIS PADA BISNIS PARIWISATA, (9).

Yoeti, O. A. (1996). Pengantar Ilmu Pariwisata. In Pengantar Ilmu Pariwisata. Bandung: Penenbit A 